\title{
Identity and Self-Other Differentiation in Work and Giving Behaviors: Experimental Evidence
}

\author{
by \\ Avner Ben-Ner, Brian P. McCall, Massoud Stephane, and Hua Wang ${ }^{1}$
}

June 2005

\begin{abstract}
The assumption that behavior is independent of the identity of those who participate in an economic interaction is fundamental to economists' understanding of how markets operate, how firms work internally, how nations trade with each other, and much else. In this paper, we show that the distinction between Self and Other, 'us' and 'them,' or in-group and out-group, affects significantly economic and social behavior. In a series of experiments with approximately 200 Midwestern students as our subjects, we found that they favor those who are similar to them on any of a wide range of categories of identity over those who are not like them. Whereas family and kinship are the most powerful source of identity in our sample, all 13 potential sources of identity in our experiments affect behavior. We explored individuals' willingness to give money to imaginary people, using a dictator game setup with hypothetical money. Our experiments with hypothetical money generate essentially identical data to our experiments with actual money. We also investigated individuals' willingness to share an office with, commute with, and work on a critical project critical to their advancement with individuals who are similar to themselves (Self) along a particular identity dimension than with individuals who are dissimilar (Other). In addition to family, our data point to other important sources of identity such as political views, religion, sports-team loyalty, and music preferences, followed by television-viewing habits, dress type preferences, birth order, body type, socio-economic status and gender, albeit statistically significant, sources of differentiation between Self and Other. The importance of the source of identity varies with the type of behavior under consideration.
\end{abstract}

\footnotetext{
${ }^{1}$ Ben-Ner, McCall and Wang are in the Industrial Relations Center (IRC), Carlson School of Management, University of Minnesota, and Stephane is at the Department of Psychiatry, Veterans Administration and University of Minnesota. The valuable assistance of graduate students at the IRC with literature review (Adib Birkland and Amandeep Ghotra) and with the administration of the experiments and data entry (Carla D'Agostino and Mark Gregware), the helpful comments made at an IRC workshop, and financial support from the Carlson School of Management, are all very much appreciated. E-mail addresses: abenner@csom.umn.edu, bmccall@csom.umn.edu, mstephan@umn.edu, hwang@csom.umn.edu.
} 
Identity and Self-Other Differentiation in Work and Giving Behaviors:

Experimental Evidence

Identity is "a person's sense of self" (Akerlof and Kranton, 2000, p. 715); it is the concept that individuals come to realize when they answer the elemental question of "who am I?" The answer, typically, includes multiple dimensions or attributes such as gender, facial features, and height, as well as religion, ethnicity, social-group affiliation, sports-team loyalty, family, profession, artistic preferences, culinary preferences, and place of origin. These attributes represent how a person views himself or herself, and are likely to have different weights to the sense of self. For example, one may identify oneself primarily as a music lover, tall, who loves to eat health food, while being a Protestant, female, or a fan of a certain team sports could be of less importance.

Generally, people act more favorably towards persons who share with them an important attribute of their identity compared to persons who differ significantly on that attribute. For example, fans of the same sports team give each other high-fives but jeer fans of a rival team; enthusiasts of certain musical groups may work more readily with those who share their preferences than with others; and members of some religious groups sacrifice their own lives but take the lives of members of other groups to advance their group's cause. Even arbitrary assignment of identity in the context of a psychology experiment can elicit partisan behavior (Tajfel and Turner, 1979; see also examples in Akerlof and Kranton, 2000:720).

The difference in how someone treats a person of the same identity - self - as compared to a person of a different identity - other - is likely to depend on several factors: the identity attribute in question, the circumstances of the interaction between subject and object, as well as the subject's individual characteristics. Many questions with regard to how different identity attributes affect behavior remain unaddressed in the social scientific literature. For example, does religion evoke more passion than ethnicity? Are all differences in identity fertile grounds for discrimination? Do differences affect equally various social and economic behaviors?

Identity is often the source of positive and desirable outcomes, such as the warm feeling of amity and affiliation, constructive and cooperative behavior in the context of social, ethnic, and religious organizations, and desirable diversity and variety. However, identity is also the basis for hatred 
and discrimination, exclusion, enmity, sports riots, national and religious wars, ethnic 'cleansing' and extermination, and other undesirable behaviors and outcomes. In this paper, we attempt to examine the weight of different attributes of identity on behavior and whether the weight of a given attribute depends on the specific behavior or activity in question.

Although it is driven by a theoretical conceptualization, the thrust of the paper is empirical and represents an exploratory analysis aimed at uncovering potential relationships between identity and behavior. We study a fairly homogenous sample of young men and women who have very little experience with strife associated with religious, national, or ethnic identities, the kind of conflicts that fuel much of the most visible identity-based behaviors. Such a sample is likely to inform about the presence or absence of deep-seated, perhaps hard-wired, sentiments about the differentiation between 'Self' and 'Other,' and behaviors driven by such sentiments, possibly mixed with culturally-transmitted values regarding such differentiation, but with only limited contribution from direct life experiences.

In a series of paper and pencil experiments, we asked the subjects to engage in various behaviors towards other (imaginary) persons bearing various identity attributes. In one experiment, subjects are invited to consider sharing an endowment of \$10 with different persons who are characterized by various social, economic, cultural and other identities. In other experiments, subjects are asked to indicate their willingness to work on a project crucial to their career, to share an office, and to commute with different imaginary persons. The behaviors elicited in these experiments correlate with altruism, cooperation and concern for others, instrumental considerations at work and in leisure activities, and also with identity attributes.

There is a large and expanding body of literature on identity in several disciplines. ${ }^{2}$ The unique contributions of the present paper include a simultaneous examination of multiple categories of identity and of their comparative strength, and a consideration of varied forms of behavior. Our results run counter to social desirability bias because even though most people in the society from which these subjects were drawn tend to behave in public in a politically correct or socially desirable manner, our subjects generally differentiated between Self and Other over several

\footnotetext{
${ }^{2}$ See the review article by Ellemers, Spears, and Doosje (2002), and literature reviews in Akerlof and Kranton (2000) and Leonard and Levine (2003).
} 
categories of identity. The paper finds significant bias in favor of Self over Other in all four forms of behavior studied in our experiments.

The paper is organized as follows: Section I explores the concept of identity and its key dimensions. Section II links identity and behaviors aimed at Self and Other. Section III offers key hypotheses. Section IV describes the experiments, the sample, the behaviors studied in these experiments, the attributes of identity under consideration, and the categories of identity that can be constructed from these attributes. Section V compares empirically behaviors towards Self and Other across 13 identity categories. Section VI concludes the paper. 


\section{The concept of identity and its attributes, and key categories of identity}

Identity, or a person's sense of self, is the outcome of a developmental process whereby differentiation between Self and Other occurs. It is a process that starts in early childhood from the undifferentiated unit of mother and child (Klein, 1969). In adulthood, identity is associated with identification with groups or categories such as gender, ethnicity, religion, musical preferences, and dressing style. A sense of self and group belonging is also observed among animals, who display the ability to recognize their kin (Fletcher and Michener, 1987 and Hepper, 1991).

Identity is the concept of which individuals become aware when they answer the elemental question of “who am I?” The answer is characteristically given with reference to multiple groups or categories and represents how a person views himself or herself (Hamachek, 1992; Akerlof and Kranton, 2000). For example, one may identify oneself as tall, a music lover, who loves to eat health food, a Protestant, a fan of certain sports teams, and so on. 'Identity' is thus a composite of multiple attributes. The relative composition and weight of each of these attributes may vary over a person's life cycle, across people, and with the circumstances of their lives (Hamachek, 1992). For example, musical preferences may be very important and religion only marginal in some persons' concept or sense of identity; the weight of ethnicity may be enhanced by the presence of multiple ethnics groups or ethnic confrontation at the expense of other attributes such as cultural or musical preferences.

Identity has genetic, cultural and neural bases grounded in an evolutionary process (Cavalli-Sforza and Feldman, 1981). Genetic relatedness, whether observed and known or only inferred and assumed, offers a strong basis for answering the question of “who am I?” If we are our genes, then the people with whom we share a greater proportion of our genes are an immediate instance of 'us' as compared to less related people. Going from identical twins, who are genetically identical, to members of an extended family, who are closely related, to members of a tribe, who share only a small proportion of common genes, and so on, the declining proportion of shared genes provides an instant basis for increasing differentiation between Self and Other; this is the key insight of Hamilton's (1964) theory of inclusive fitness. Since genetic similarity can only rarely be observed directly, individuals may use clues that may be correlated with genetic identity: ethnicity, skin 
complexion, religion, culinary preferences, place of origin, physical similarity, etc. (van den Berghe, 1999).

Evolutionary theorists, biologists and psychologists, note the value of steady affiliation with a group, and claim that the desire to belong to a group may be hard wired in some species, including humans. Group affiliation provides physical protection (Shaw and Wong, 1989), facilitates the ability to read facial, behavioral, or linguistic clues regarding feelings such as guilt and the detection of lying, which confers an obvious advantage (Wilson, 1978), and facilitates reciprocity, a key element of sustained cooperation (Ben-Ner, Putterman, Kong and Magan, 2004).

Other sources of identity may have little to do with genetic relationship. Group affiliation may be based on demographic characteristics such as age and generation, or on functional association, such as a work group, neighborhood, common interest, culture, or hobby; therefore, the range of possible identities is very large. One theory that advances this view, social identity theory (Tajfel and Turner, 1979), is widely accepted among sociologists and social psychologists. ${ }^{3}$

Many identity attributes have been recognized in the literature, and those have been aggregated into a set of broad, partly overlapping categories. Most of these categories can be derived without much stretch from all three theories. The panel below lists the most important categories that appear in the literature, and when available, cites references that elaborate on each category from diverse theoretical perspectives.

\footnotetext{
${ }^{3}$ For an expansive discussion of this and related theories, see Ellemers, Spears, and Doosje (2002).
} 


\section{Broad Identity Categories}

\begin{tabular}{|l|l|}
\hline Identity Category & Literature \\
\hline Family and kinship & Shaw and Wong (1989); Sökefeld (1999); Alderfer (1997); van den Berghe (1999) \\
\hline Gender & Davis (2000); Akerlof and Kranton (2000); Barkow (1989); Dickson and Pollack (2000); Wade (2001) \\
\hline Occupation & Spreitzer et al. (1974); Cartwright et al. (1978); Becker and Carper (1956); Savickas (1999) \\
\hline Ethnicity & Barkow (1989); Dien (2000); Alderfer (1997); Davis (2000); Devos (1974); van den Berghe (1999) \\
\hline Culture & Sökefeld (1999; Dien (2000); Davis (2000); Devos (1974) \\
\hline Nationality & Dien (2000); Wade (2001) \\
\hline Race & Abdullah (1998); Alderfer (1997); Davis (2000); Hirschfeld (1995); Wade (2001) \\
\hline Religion & Barkow (1989); Miller et al. (2001); Sökefeld (1999) \\
\hline Political philosophy & Miller et al. (2001) \\
\hline Dress style & Miller et al. (2001); Dickson and Pollack (2000); Hayes (2000) \\
\hline Community type & Hummon (1986); Davis (2000) \\
\hline Interests & Hummon (1986); Pitts (2002) \\
\hline Hobbies and leisure & Spreitzer et al. (1974); Anderson and Farris (2001); Baughman (2000); Dickson and Pollack (2000) \\
\hline Knowledge & Hummon (1986) \\
\hline Sentiment & Hummon (1986) \\
\hline Generation and age & Alderfer (1997); Dickson and Pollack (2000) \\
\hline Socio-economic status & Cartwright et al. (1978); Akerlof and Kranton (2000); Devos (1974) \\
\hline Musical preference & Brown (2000); Pitts (2002); Tarrant et al (2001); Wade (2001) \\
\hline Sexual preference & Brown (2000); Wade (2001) \\
\hline
\end{tabular}

The literature suggests that individuals tend to assign people with whom they interact to a class of Self or Other ('us' or 'them') according to these categories. The Self-Other differentiation may go beyond a stark dichotomy; for instance, individuals distinguish among immediate relations such as parents and siblings, more distant relatives, such as cousins, and even more distant members of an extended family, and likewise, some religions or denominations within broad religions may be considered closer to each other than to others. However, there is also a strong tendency to make a simple division between Self and Other, in-group and out-group, 'us' and 'them;' we will follow such a dichotomy in the remainder of this paper. ${ }^{4}$

\footnotetext{
${ }^{4}$ For an argument that human beings process information with the aid of categories rather than more detailed attributes, see Fryer and Jackson (2003).
} 


\section{Identity and behavior: behaviors aimed at Self and Other}

Humans seem to have a deep-rooted propensity to respond emotionally to symbolic representations of members of their in-group by exhibiting spontaneous joy, pride, and so on (Isaacs, 1975; Tönnesmann, 1987), and these emotions are aroused and reinforced through the language of kinship and the use of rituals, flags, anthems, marches, and so on (Johnson, 1995). It has been widely noted that individuals engage in more favorable behaviors towards people who share with them some salient identity attributes than towards people who are different from them. Behaviors and relationships affected in this fashion by the Self-Other differentiation or 'us' vs. 'them' have been discerned in many contexts, such as conflict (Shaw and Wong, 1989), teacherstudent relations (Akerlof and Kranton, 2002; Hamachek, 1992), manager-subordinate interactions (Boone et al., 1999; Akerlof and Kranton, 2000), job performance (LePine and Van Dyne, 2001), and occupational choice (Cartwright et al., 1978).

The preference for a partner in an activity is likely to be affected by identity considerations, along with other factors. Similarity in identity may entail more trust, reciprocity, efficiency due to shared language, norms, or understandings, and fewer concerns about being taken advantage of, as well as engender in some individuals a greater willingness to make sacrifices. Identity may also be a clue to possession of instrumental skills (such as occupational and educations status), or for a special need (such as socio-economic status), in which case similarity and difference in identity may be less important. Identity and other considerations may be mutually reinforcing in a certain behavior, such as in the case of potential cooperation between two professionals whose qualifications play an important role in their identities, or may counteract each other, for example with a champion swimmer saving a non-swimmer from drowning.

The theories reviewed earlier predict that individuals will treat more favorably other individuals whom they consider Self than those whom they regard as Other. The theory of inclusive fitness suggests that an individual will act more solicitously towards those who share with him or her greater proportion of their genetic material, because genes that incline their bearers to be caring toward those who carry similar genes would have been selected in the process of human evolution. As noted earlier, some kin relationships, particularly if distant, may not be known specifically to the affected individuals, yet they may be correlated with observable or knowable characteristics 
such as looks, ethnicity, religion, and place of origin; individuals who are similar with respect to such characteristics may therefore treat each other more favorably than individuals who are dissimilar. More generally, fitness advantages may have accompanied those individuals who were willing to commit strongly to groups in terms of choosing actions that favor those within a group more strongly than those outside the group. Evolutionary theory then implies these individuals would become more prevalent in populations over time. Thus, individuals may have a hardwired tendency for group commitment. Moreover, evolutionary theory predicts that the strength of this commitment across different types of groups should vary directly with the group's ability to affect an individual's and his or her descendants' survival. The social identity theory equally predicts that behavior towards in-group members will be more favorable than towards out-group members. Studies have demonstrated that people generally favor Self over Other in distribution of rewards (Brewer, 1979; Tajfel and Turner, 1986; Brewer and Brown, 1998), and that they attribute more positive views to in-group members than to out-group members (Allen 1996; Rustemli, Mertan, and Ciftci, 2000). ${ }^{5}$ This theory does not provide a criterion for predicting the degree of solicitousness towards groups belonging to different categories of identity, as the inclusive fitness theory does with respect to family relations.

Indeed, there is ample direct evidence that identity matters for behavior: ethnic, national, and religious wars dot history, discrimination on the basis of almost any conceivable grounds is commonplace, and a visit to a schoolyard during recess shows how children divide into random teams to play a ball game and develop instantly strong feelings towards members of their own team and their temporary adversaries. In a series of experiments, Tajfel and Turner (1986) divided subjects arbitrarily into groups according to preferences for painting styles, and then asked members of different groups to share money with members of their own preference group or other groups. Those who were assigned to a particular preference favored persons who were assigned the same preference. These dictator-game like experiments showed how important are in-group and out-group identities, irrespective of their arbitrariness. Other studies found a gender effect on giving in dictator-game experiments (see Andreoni and Vesterlund (2001) and Ben-Ner, Kong and Putterman (2004)) and trust game experiments showed differences in trusting on ethnic and

\footnotetext{
${ }^{5}$ Allen (1996) found an in-group bias effect for individuals of European and African descent, such that both groups attributed more positive traits to members of their respective in-group.
} 
national lines (see Glaeser et al. (2000), Fershtman and Gneezy (2001), and Bornhorst et al. (2004)).

In summary, theory suggests that identity affects behavior in a way that favors Self relative to Other in different identity categories. The inclusive fitness theory suggests that family and kin relations constitute the most important identity category, with other categories possibly associated with genetic similarity following suit. Evolutionary theory predicts that long-term affiliation is valuable, pointing to the same categories as inclusive fitness theory, and to groups with which individuals tend to be attached for long periods of time and where they can get to know each other, such as small communities and workplaces, membership organizations, and so on. Social identity theory only identifies the importance of social categories for belonging without providing a clear basis for their ordering in terms of importance for behavior.

Is differentiation between Self and Other the only engine of behavior? Of course not: there are additional influences on individual behavior. ${ }^{6}$ In particular, rational individuals may well temper their identity-based instinct with instrumental considerations, leading to the possibility that identity plays a greater role in situations where instrumental considerations are less important, such as in leisure activities, and a lesser role in activities such as work where skills and knowledge are crucial. On the other hand, similarity in identity may provide advantages from enhanced trust and cooperation, ${ }^{7}$ generating the alternative possibility that identity plays a greater role in situations such as the workplace and many business interactions where cooperation and trust are important. We conjecture that the balance between these two forces will vary across activities relative to their requirements of skill, knowledge, trust and cooperation.

\footnotetext{
${ }^{6}$ See for example Ben-Ner and Putterman (2000) who attempt to sort out conceptually various influences.

${ }^{7}$ This is the familiar trade-off between loyalty and expertise in family-owned firms or state-owned firms in communist countries.
} 


\section{Hypotheses}

A. Self is favored over Other in economic, work, social, and leisure interactions.

B. Identity categories have varying degrees of influence over how much Self is favored over Other; the strongest source of identity is kinship.

C. The effects of identity vary across activities and behaviors. 


\section{The experiments}

We designed four experiments that capture various behaviors in social and economic situations aiming to: 1) test the hypothesis that the Self-Other differentiation affects behavior, 2) explore the differences in the strength of different identity categories, and 3) investigate differences across types of behavior relative to identity categories. In the four experiments subjects were asked to express their willingness to give money to, work with, share an office with, and commute with different persons characterized by various identity attributes. Information was gathered about subjects through a background survey, a personality inventory, and a cognitive ability test that subjects completed at the end of the experiments. The survey permitted the creation of Self and Other variables indicating whether a subject was similar to or different from each of the various imaginary persons with whom they were paired. Our subjects were 220 first-year undergraduate students at the University of Minnesota.

\section{Experimental design}

The first experiment was designed as a zero-sum, one-shot game, where the subjects were asked to “... imagine yourself in a situation in which you are given $\$ 10$, which you can keep to yourself or give to another person, all or any portion of it." Subjects were asked to consider sharing their hypothetical (imaginary) \$10 endowment with another (imaginary) person. This experiment mimics the familiar dictator game that is carried out with actual money. The dictator game is a-one person decision process: one player, the 'dictator,' divides a fixed amount of money between himself or herself and another person, the recipient, who is entirely passive and has no say in the decision. In this situation, giving any amount to the other person costs the subject exactly that amount, dollar for dollar. Because a selfish subject who understands the extremely simple structure of the game would give nothing, the common interpretation is that any giving implies caring, altruism and unconditional cooperation towards the other person. This experiment is thus especially relevant to the question concerning differential caring for Self and Other. Although this experiment involved no real money, the findings derived from it are very similar to those from similarly-structured economic dictator-game experiments carried out with a \$10 endowment and with a similar pool of subjects. Subjects give essentially the same amounts from a $\$ 10$ 
endowment, whether the endowment consists of an actual or of a hypothetical endowment (BenNer and Levy, 2005).

In addition to the explicitly economic situation of giving money, we examined hypothetical behaviors in work and social situations. In three other separate experiments subjects were asked to answer 'yes' or 'no' to three questions: “do you want, or not want, to commute daily to school with a particular person," "do you want, or not want to work with a particular person on a project critical to your career advancement," and "whether you like or dislike sharing an office with this person." Working on a project critical to one's promotion requires a choice of partner who can be trusted to cooperate, reciprocate and generally act favorably to one's interests, and who is likely to be a good worker. Sharing an office is an ongoing activity that has milder instrumental implications and stronger social-compatibility requirements. Commuting together is an activity of short duration that entails social interactions without any instrumental elements. Note that the questions were phrased in terms of "want" with respect to working and sharing office, and in terms of "like" regarding commuting.

Our expectation has been that identity would engender stronger differentiation in the 'giving' and 'working together' than in 'sharing an office' or 'commuting.' In each experiment subjects were paired separately and sequentially with 91 different persons characterized in ways that are directly associated with an identity category.

The subjects

All freshmen at the University of Minnesota (approximately 5,000) were invited by email to participate in economic-psychological experiments; nearly 10\% responded, with 222 actually showing up at the experiment. The average age of the sample was 18.8 years with $92.8 \%$ of individuals being between 18 and 21. A majority of the sample was female (64.0\%) and 71.4\% were Caucasian. 
After the completion of the experiments, we administered a personality inventory, a cognitiveability test, and a background survey. These are not analyzed in this paper, and therefore will not be described here. ${ }^{8}$

\section{Empirical specification of Self and Other and of identity categories}

In this paper, of the 91 imaginary persons listed in the experiments we used only those that fit into one of the following categories of identity: family, political views, sports-team loyalty, music preferences, nationality, religion, socio-economic status, television viewing habits, food preferences, birth order, body type, dress type, and gender. These 13 categories correspond to most of the categories presented in section I. Table 1 illustrates the bases for creating the Self and Other variables. This was done by matching persons listed in the experiments with corresponding characteristics reported in the background survey. For example, if a subject indicated on the survey that s/he is Protestant, then the Self-Other variable was coded as Self for a person described as Protestant in the experiment list, and was coded as Other for a person described as Buddhist, Muslim, or Jewish. For a subject shorter than 66" (for males), the variable was coded as Self for a person described in the experiment as short, and Other for tall.

An identity category generally consists of multiple attributes or items, and we create the giving, commuting with, working with, and sharing office with variables by taking the average over the items in each category. For example, there are multiple musical preferences, several religions, different ways of characterizing body type, and so on. In the body type category, for example, we use the average of two items, height and weight. In the sports-team loyalty, we use only one item, fan of one's team versus fan of a rival team. In most categories, the Self and Other designations are natural differences, or even opposites. In the family and kinship category, Self includes family relations of varying degrees, as well as persons described as "looks like you" and "resembles you.” The last two items were included because clues to genetic closeness are associated with looks. 'Other' for this category is the person described as a 'stranger,' the obvious non-kin. ${ }^{9}$

\footnotetext{
${ }^{8}$ The experiments are at http://webpages.csom.umn.edu/hrir/abenner/web/papers/IDexperiment.pdf

${ }^{9}$ Other characterizations, such as "someone you've seen crossing the street” and "someone you've seen at the checkout counter at the supermarket” are less loaded that the term "stranger” but produce similar results.
} 


\section{The relationship between identity and behavior: empirical findings}

Figure 1 displays the sample averages and proportions broken down by Self and Other for each identity category, by type of behavior. The upper left panel shows that for all identity categories, with the exception of gender, mean levels of giving are larger for Self than for Other. The differences are particularly large for the family, religion, political views, sports-team loyalty and music preferences categories. Similar results are seen in the remaining panels of Figure 1 for the proportions of subjects liking to share an office, wanting to commute, or wanting to work with another person. The identity categories in Figure 1 are listed from the smallest Self-Other difference in giving to the largest. The largest average difference for all four behaviors is for the family category: for giving, the Self-Other difference is $\$ 2.93$, while for the share office, commute and work behaviors the Self-Other differences are 0.28, 0.52 and 0.53 , respectively. The smallest average Self-Other difference for giving is for the gender category (\$-0.14), for share office the body type category (-0.016), for work is the body type category $(-0.005)$, and for commute is the gender category (-0.013). A slightly higher proportion of subjects favor Other than Self in the gender category, for the giving and commute behaviors; Other in the body type identity category is also shown a slightly more favorable attitude, on average, than Self in the share office, work and commute behaviors but not in giving.

The raw averages presented in Figure 1 suggest that (1) Self is treated more favorably than Other, with very minor exceptions, (2) there are marked differences in the way Self and Other are treated across identity categories, and (3) there are differences across behaviors. The remainder of this section explores these points in more detail and relative to the hypotheses enumerated in section III.

(a) In order to further investigate Self-Other differences by identity category and behavior type, we estimated fixed-effects regression and fixed-effects logit models. For the level of giving, we assumed that

$g_{i q}=\beta_{0}+\alpha_{i s}+\alpha_{i o}+\sum_{c \in C} \beta_{s c} I(q=\{c, s\})+\sum_{c \in C} \beta_{o c} I(q=\{c, o\})+\varepsilon_{i q}$ 
where $i$ denotes the individual, $q$ denotes the particular imaginary person that subject $i$ is paired with, $c$ denotes the identity category under consideration, $c \in\{1, \ldots, C\}$, s denotes whether the imaginary person $q$ is of the Self type and $o$ the denotes whether the imaginary person $q$ is of the Other type. The parameters $\alpha_{\text {is }}$ and $\alpha_{i o}$ are individual fixed effects for imaginary people who fall into the Self and Other types, respectively. Thus, these parameters measure the average giving to Self and Other across all identity categories for a particular individual. The parameters $\beta_{s c}$ and $\beta_{o c}$ measure the category deviation from the person-specific mean for Self and Other types. For simplicity, we have assumed that these deviations themselves are not person specific. Finally, $\varepsilon_{i q}$ is an individual-imaginary person specific error term. For the commute, work and share office behaviors the fixed-effects logit model

$\ln \left(\frac{p_{i q}}{1-p_{i q}}\right)=\beta_{0}+\alpha_{i s}+\alpha_{i o}+\sum_{c \in C} \beta_{s c} I(q=\{c, s\})+\sum_{c \in C} \beta_{o c} I(q=\{c, o\})$

is estimated, where $p_{i q}$ represents the probability that individual $i$ says "yes" to the question posed that pertains to imaginary person $q$.

Table 2 presents estimates of $\hat{\beta}_{s c}-\hat{\beta}_{o c}$, the Self-Other differences, by identity category, in the four experiments; these estimates are based on the estimates of the fixed-effects models described by equations (1) and (2). The full set of fixed-effect estimates is presented in the Appendix Table A1. Column (1) presents estimates based on the fixed-effects regression estimates for the giving experiment, whereas columns (2)-(4) present estimates based on the fixed-effects logit estimates for the share office, work and commute experiments, respectively.

The message conveyed by Table 2 is rather strong: Self is significantly favored over Other in all four experiments in nearly all identity categories. Exceptions are glaringly few: a small and statistically insignificant difference in preference for giving to Other than Self in the socioeconomic status category (probably explained by the fact that many who are well-off, as well as most others, prefer to give money to the poor rather than the well-off), and a small advantage given to Other over Self in the gender category (probably explained by asymmetries in ways that men and women treat each other detected in dictator game experiments by Ben-Ner, Kong and Putterman, 2004). We conclude that hypothesis A is supported by our experimental evidence. 
(b) The results in column (1) show large differences in giving to Self versus Other for the family, sports-team loyalty, political views, food preferences, religion, music preferences and nationality categories, smaller yet statistically significant differences for birth order, dress type and body type, and negative but insignificant differences for the socio-economic and gender categories. For giving, we can reject the null hypothesis that the Self-Other difference is independent of identity category $(F=21.99$, p-value $=0.000)$. For sharing an office, and commuting and working with another individual, we also soundly reject $(\mathrm{p}$-value $=0.000)$ the null hypothesis that the Self-Other difference is independent of identity category $\left(\chi^{2}(12)=115.83, \chi^{2}(12)=208.93, \chi^{2}(12)\right.$ $=201.56$, respectively). Thus, while individuals tend to favor individuals who are similar to themselves over individuals who are different, the extent of such favoritism varies substantially across identity categories. Table 2 therefore provides support for the main part of hypothesis B.

In order to explore hypothesis B in more detail and gain insight into the relative importance of various identity categories, we analyzed the relative ranks of the Self-Other differences by identity category. Our point estimates for the giving experiment show that the family category has the largest Self-Other difference followed by sports-team loyalty, political views, and religion and music preferences. What is the likelihood that this ordering is due to chance? We used bootstrapping techniques using 1000 replications to examine the rank-order distribution. Bootstrapping treats the sample as a population and then re-samples with replacement a number of times and computes relevant statistics for each replacement sample. The empirical distribution of the bootstrapped sample statistics are then used to address questions of statistical significance (see Efron and Tibshirani, 1993, for details). Here we analyze the bootstrapped samples’ empirical distribution of relative ranks. Because of the computational complexity of estimating the fixed effects logit model, the rank order of Self-Other differences was bootstrapped only for the giving experiment, which was based on a fixed-effects regression model. The results are presented in Table 3. For each identity category, the table reports the mean rank and the 5th and 95th percentiles of the rank distribution based on the 1000 replications. For example, the Self-Other difference for the religion category was ranked on average 4.5 across all identity groups while in the upper $5 \%$ of the replications the difference was ranked third or higher and in the lower 95\% of the replications the difference ranked sixth or lower. 
The Self-Other difference was largest for the family category in all 1000 replications. The next two highest mean ranks were for the sports-team loyalty and political views categories. However, since sports-team loyalty was ranked higher than political views only in $55 \%$ of the replications, the difference in mean ranks is not statistically significant. The fourth and fifth highest mean ranks for giving were the religion and music preferences categories, respectively. Since the Self-Other difference for religion was larger than that for music preferences in only $52 \%$ of the replications, the rank differences are not statistically significant. When comparing sports-team loyalty to the religion and music preferences categories, the Self-Other differences for the sports-team loyalty category are larger than both religion and music preferences categories in over 95\% of the replications. Thus, the rank differences are statistically significant. The political views Self-Other difference was larger than the religion and music preferences differences for giving in 90 and $91 \%$ of the replications, respectively. The evidence is therefore not as strong as for sports-team loyalty.

The rank ordering of identity categories obtained from bootstrapping replications is, not surprisingly, essentially the same as that implied by the relative magnitude of differences in giving across identity categories in the fixed-effects regression reported in column (1) of Table 2 . The rank ordering of different identity categories for the other behaviors presented in columns (2)-(4) is similarly implied by the relative magnitude of the estimated differences for each behavior. The order of importance of identity categories varies across the four columns, but the preeminent role of family persists across behaviors. Family is far ahead of other categories in terms of the preference given to those who are Self versus Other with respect to giving (estimated difference of 4.264 as compared to 2.586 for sports-team loyalty, the next largest difference), work (estimated difference of 9.225 as compared to 6.798 for music preferences, the next largest difference), and commute (estimated difference of 9.938 as compared to 5.364 for nationality, the next largest difference); in the share-office experiment the estimated difference between Self and Other for family is just slightly smaller than the difference for music preferences (7.063 versus 7.475). Thus, in addition to the main point of hypothesis B, the key secondary postulate generated by the inclusive fitness theory, that kin relations constitute the most important identity category, is also supported by our findings. The postulate regarding the importance of identity categories linked to long-term affiliation cannot be tested without classifying identity categories according to the duration of affiliation. Such a classification is not available in the literature, and is a task that is well beyond the scope of this paper. 
(c) Hypothesis C suggests that the importance of similarity in identity varies across behaviors. While we are unable to compare directly parameter estimates from regression and logit analyses, we can do so across the logit analyses concerning the share office, work, and commute behaviors. In order to evaluate the importance of similarity for a given identity category we tested the equality of the (Self) $\mathbf{x}$ (identity category) coefficients across the share-office, work and commute behaviors; the chi-square tests reject the null of equality at the $1 \%$ level for the identity categories of family, music preferences, and sports-team loyalty (and for dress type and birth order at the $10 \%$ level). As the parameter estimates on (Self) $\mathbf{x}$ (identity category) in Appendix Table A1 suggest, our subjects value more commuting and working with their kin than sharing an office with them, and they prefer commuting with someone who shares their musical preferences and sports-team loyalty, but this similarity does not seem to be very important for sharing an office and certainly not for working on a critical project. In other categories similarity (rather than difference) in identity does not seem to play a role.

To explore this hypothesis in more detail we compared behaviors towards Self and Other across the three behaviors by carrying out pair-wise tests of equality between the logit estimates in columns (2)-(4) of Table 2 for each identity category. The chi-square tests and direction of the difference in estimates are presented in Table 4. There bias in favor of Self versus Other is statistically different and substantial across the three types of behaviors in the case of only two identity categories: family and music preferences. The differentiation between Self and Other in the family category is greater in the work and commute behaviors than in the share-office behavior, whereas in the case of music preferences the bias is larger for the share office and commute behaviors than for work. The music preferences category is likely to bear more on compatibility in social situations such as commuting and sharing an office than on trust and cooperation and therefore the order we just discussed makes sense. The family category probably bears more on trust and cooperation than on compatibility in social settings and therefore should be more important for work than sharing an office or commuting; the former relationship is found in our data, but not the latter. Less significant differences (at the $5 \%$ level) concern sports-team loyalty, which is more important for sharing an office and commuting than for work, similar to music preferences, and dress type, which is more important for commuting than for work, again similar to music preferences. 
Hypothesis $C$ is thus generally supported by these findings, which suggest that some identity categories are more important for activities in which trust and cooperation is central (work), and others are more important for behaviors that entail a large element of social interaction. However, for the several remaining identity categories there is no strong differential impact by identity on behavior. 


\section{Conclusions}

The assumption that behavior is independent of the identity of those who participate in an economic interaction is central to economists' understanding of how markets operate, how firms work internally, how nations trade with each other, and much else. On the basis of this assumption economists have been strong proponents of globalization, of the diminution of economic and political boundaries, and of the expansion of market principles to non-economic arenas. In this paper we show that the distinction between Self and Other, 'us' and 'them,' or in-group and outgroup, affects significantly economic and social behavior. In a series of experiments with Midwestern students as our subjects we found that they favor those who are similar to them on any one of a wide range of categories of identity over those who are not like them. Whereas family and kinship (including persons described as "looks like you” and "resembles you” in addition to various relatives) are the most powerful source of identity in our sample, it appears that there is no inconsequential source of identity: if an identity category happens not to affect one type of behavior then it will affect other behaviors.

Our findings indicate that people are more willing to give to, share an office with, commute with, and work on a critical project critical to their advancement with individuals who are similar to themselves (Self) along a particular identity dimension than with individuals who are dissimilar (Other). However, the magnitudes of these differences depend on the particular identity category. In particular, we found strong evidence that in the context of a dictator game experiment, the SelfOther differences in giving behavior are largest for the family and kinship category. The evidence also points towards this conclusion for working and commuting preferences, and essentially so in sharing an office preference. These results are consistent with evolutionary models of inclusive fitness.

Other identity categories in which the Self-Other distinction is important are political views, religion, sports-team loyalty, and music preferences. Although other interpretations are possible, the first two identity categories (and to some extent the third) may be viewed as modern-day equivalents of tribal or hunting-band affiliation of yore when belonging to groups was particularly important for survival and, thus, may have evolutionary roots. From the same theoretical perspective we would expect that nationality would be a strong basis for identity; surprisingly, 
although it is a source of differentiation between Self and Other for our subjects, nationality ranks low for the giving behavior, lower than television viewing and dress type, for example, and is really high only for the commuting experiment.

The finding of strong differentiation between Self and Other along so many diverse sources of identity and over such a wide range of behaviors suggests that economists have to pay attention to the economic role of identity. Ignoring the influence of identity does not advance economic analysis, and certainly does not supply a solid basis for good policy. Our findings of course do not mean that globalization, the diminution of economic and political boundaries, and the expansion of market principles to non-economic arenas are not desirable. Nor do our findings mean than diversity in the workplace is not desirable, or that discrimination can be justified because it may be due in part to tendencies inherited over many generations. But these findings do call attention to the need for much more nuanced analyses than what the standard economic assumption would beg.

Our sample exhibited significant identity-based behaviors, but given the sample's very specific demographic characteristics it is impossible to generalize our findings to other samples. The large literature on identity has shown that identity matters in a variety of samples; however, there is no literature that evaluates different identity categories’ relative importance, or the effect of identity for different activities, and it would be valuable to study other samples in order to throw light on the question whether the ranking of identity categories varies with culture, historical experiences, and other circumstances.

As it provides tentative answers to several questions, the paper also stimulates additional research questions: (a) how do individual differences in personality, cognitive ability, family background, personal experiences and more affect identity-based behavior, (b) what is the interplay between rational economic action and action driven by identity considerations, and (c) what happens when identity is under stress from changes in the environment ${ }^{10}$ Answering these questions may throw additional light on the role of identity in complex economic life and further our understanding of

\footnotetext{
${ }^{10}$ We are exploring question (a) in a forthcoming paper. Akerlof and Kranton (2000) established some principles for dealing with questions (b) and (c). An elegant treatment of one aspect of question (b) is provided by Ortona (2002) who proposes a theory of mass ethnic violence produced by rational subjects fueled by various 'non-economic' passions. An initial step in the direction of question (c) is made by Giuriato and Molinari (2002) who study some effects of 'lacerations in identity.'
} 
how individuals from diverse backgrounds may interact with each other in the workplace and in the marketplace, and how larger groups including nations, homogeneous on some dimensions but not on others, may manage affairs of mutual concern. 


\section{REFERENCES}

Akerlof, George A. and Rachel E. Kranton, "Economics and Identity,” The Quarterly Journal of Economics, 115 (August 2000), 715-753.

Akerlof, George A. and Rachel E. Kranton, "Identity and Schooling: Some Lessons for the Economics of Education,” Journal of Economic Literature, 40 (December 2002), 1167-1201.

Alderfer, Clayton P., "Embedded Intergroup Relations and Racial Identity Development Theory.” In C. E. Thompson (Ed.), Racial Identity Theory: Application to Individual, Group, and Organizational Interventions (Mahwah, NJ, US: Lawrence Erlbaum Associates, Inc. 1997), 237263.

Allen, Ben P., "African Americans' and European Americans' Mutual Attributions: Adjective Generation Technique (AGT) Stereotyping,” Journal of Applied Social Psychology, 26 (1996), 884-912.

Anderson, Cheryl B., George D. Farris, "Athletic Identity Among $8^{\text {th }}$-grade Adolescents: Definitions, Ratings, and Physical Activity.” Medicine \& Science in Sports \& Exercise, 33 (Supplement 5 2001), 222.

Andreoni, James and Lisa Vesterlund, “Which is the Fair Sex?” Quarterly Journal of Economics, 116 (February 2001), 293-312.

Barkow, Jerome H., Darwin, Sex, ands Status: Biological Approaches to Mind and Culture. (Buffalo, NY, US: University of Toronto Press. 1989)

Baughman, K. R., "The Social-Psychological Benefits of Sports and Fitness Identities," Dissertation Abstracts International, 61(3-A), (2000), 1180.

Becker, H. S. and J. W. Carper, "The Development of Identification with an Occupation,” American Journal of Sociology, 61 (1956), 289-298.

Ben-Ner, Avner and Ori Levy, "Economic and Hypothetical Dictator Game Experiments: Incentive Effects at the Individual Level,” Working Paper, Industrial Relations Center, Carlson School of Management, University of Minnesota (March 2005). http://webpages.csom.umn.edu/hrir/abenner/web/papers/econhypotdict.pdf

Ben-Ner, Avner, and Louis Putterman, "On Some Implications of Evolutionary Psychology for the Study of Preferences and Institutions," Journal of Economic Behavior and Organization, 43 (2000), 91-99.

Ben-Ner, Avner, Fanmin Kong, and Louis Putterman, "Share and Share Alike? Gender-Pairing, Personality, and Cognitive Ability as Determinants of Giving,” Journal of Economic Psychology, 25 (October 2004), 582-589. 
Ben-Ner, Avner, Louis Putterman, Fanmin Kong and Dan Magan, "Reciprocity in a Two Part Dictator Game,” Journal of Economic Behavior and Organization, 53 (March 2004), 333-352.

Boone, Christophe, Bert De Brabander and Arjen van Witteloostuijn, “The Impact of Personality on Behavior in Five Prisoner’s Dilemma Games,” Journal of Economic Psychology, 20 (1999), 343-377.

Bornhorst, Fabian, Andrea Ichino, Karl Schlag and Eyal Winter, "Trust and Trustworthiness among Europeans: South-North Comparisons,” Department of Economics, European University Institute, Working Paper (May 2004).

Brewer, Marilynn B., "In-group Bias in the Minimal Intergroup Situations: A Cognitive Motivational Analysis,” Psychology Bulletin, 86 (January 1979), 307 - 324.

Brewer, Marilynn B and Rupert J. Brown, “Inter-group Relations,” Gilbert, Daniel T. and Susan T. Fiske, eds. The Handbook of Social Psychology, 1998, vol. 2 (4th ed.), 554-594.

Brown, Steven, “Evolutionary Models of Music: From Sexual Selection to Group Selection,” In Tonneau, F., and Thompson, N. S. eds., Perspectives in Ethology: Evolution, Culture, and Behavior, 13 (New York, Kluwer Academic/Plenum Publishers, 2000).

Cartwright, R. A., H. J. Hargreaves and E. Sunderland, "Social Identity and Genetic Variability," Journal of Biosocial Science, 10 (January 1978), 23-33.

Cavalli-Sforza, Luigi Luca, and Marcus W. Feldman, Cultural Transmission and Evolution: A Quantitative Approach (Princeton, New Jersey: Princeton University Press, 1981).

Davis, Dena S., “Groups, Communities, and Contested Identities in Genetic Research,” Hastings Center Report, 30 (June 2000), 38-45.

Devos, George, "Social Stratification and Ethnic Pluralism: An Overview from the Perspective of Psychological Anthropology,” Race, 13 (April 1972), 435-460.

Dickson, Marsha A. and Ashley Pollack, “Clothing and Identity Among Female in-line Skaters,” Clothing and Textiles Research Journal, 18 (February 2000), 65-72.

Dien, Dora S., “The Evolving Nature of Self-Identity Across Four Levels of History,” Human Development, 43v (January 2000), 1-18.

Efron, Bradley, Robert J. and Tibshirani, An Introduction to the Bootstrap ( New York, NY: Chapman \& Hall., 1993).

Ellemers, Naomi, Russell Spears and Bertjan Doosje, "Self and Social Identity,” Annual Review of Psychology, 53 (2002), 161-186.

Fershtman, Chaim and Ury Gneezy, "Discrimination in a Segmented Society: An Experimental Approach,” Quarterly Journal of Economics, 116 (March 2003), 351-377. 
Fletcher, David JC. and Charles D. Michener, Kin Recognition in Animals (New York: John Wiley, 1987).

Fryer Jr., Roland G. and Matthew O. Jackson, “Categorical Cognition: A Psychological Model of Categories and Identification in Decision Making,” NBER Working Paper 9579 (2003).

Giuriato, Luisa and Maria Cristina Molinari, "Rationally Violent Tactics: Evidence from Modern Islamic Fundamentalism,” in Albert Breton, Gianluigi Galeotti, Pierre Salmon, and Ronald Wintrobe, eds. (Cambridge University Press, 2002).

Glaeser, Edward L., David I. Laibson, José A. Scheinkman, and Christine L. Soutter, "Measuring Trust,” Quarterly Journal of Economics, 115 (August 2000), 811-846.

Hamachek, Don E., Encounters with the Self (4 ${ }^{\text {th }}$ ed.) (San Diego, CA, US: Harcourt Brace Jovanovich, Inc., 1992).

Hamilton, William D., “The Genetical Evolution of Social Behavior: I,” Journal of Theoretical Biology, 7 (July 1964), 1-16.

Hayes, James B., “Antecedents and Consequences of Brand Personality,” Dissertation Abstracts International, 61(1-A), 2001, 268.

Hepper, Peter G., Kin Recognition (Cambridge: Cambridge University Press, 1999).

Hirschfeld, Lawrence A., “The Inheritability of Identity: Children’s Understanding of the Cultural Biology of Race,” Child Development, 66 (1995), 1418-1437.

Hummon, David M., "City Mouse, Country Mouse: The Persistence of Community Identity,” Qualitative Sociology, 9 (January 1986), 3-25.

Isaacs, Harold L. Idols of the Tribe: Group Identity and Political Change (New York: Harper \& Row, 1975).

Johnson, Gary R., “The Evolutionary Origins of Government and Politics,” in A. Somit \& J.A. Losco, eds. Research in Biopolitics, 2 (1995), 243-305.

Leonard, Jonathan S. and David I. Levine, “Diversity, Discrimination and Performance.” Institute of Industrial Relations Working Paper Series. 2003 University of California, Berkeley. http://repositories.cdlib.org/iir/iirwps/-091-03/

Klein, Melanie, The Psycho-analysis of Children (London, The Hogarth Press and the Institute of Psychoanalysis, 1969).

LePine, Jeffery A. and Van Dyne, Linn, "Voice and Cooperative Behavior as Contrasting Forms of Contextual Performance: Evidence of Differential Relationships with Big Five Personality Characteristics and Cognitive Ability,” Journal of Applied Psychology, 86 (April 2001) 326-336. 
Miller, Bruce L., William W. Seeley, Paula Mychack, Howard J. Rosen, Ismael Mena and Kyle Boone, "Neuroanatomy of the Self: Evidence from Patients with Frontotemporal Dementia," Neurology, 57 (September 2001), 817-821.

Ortona, Guido, “De Bello Omnium ${ }_{\mathrm{i}}$ Contra Omnes $_{\mathrm{j}}$ ”” in Albert Breton, Gianluigi Galeotti, Pierre Salmon, and Ronald Wintrobe, eds. (Cambridge University Press, 2002).

Pitts, Stephanie E., “Changing Tunes: Musical Experience and Self-perception Amongst School and University Music Students,” Musicae Scientiae, 6 (January 2002), 73-92.

Rustemli, Ahmet, Biran Mertan and Orhan Ciftci, "In-group Favoritism Among Native and Immigrant Turkish Cypriots: Trait Evaluations of In-group and Out-group Targets,” The Journal of Social Psychology, 140 (February 2000), 26-34.

Shaw, R. Paul and Yuwa Wong, Genetic Seeds of Warfare (Cambridge, MA, US: Unwin Hyman, 1989).

Sökefeld, Martin, “Debating Self, Identity, and Culture in Anthropology,” Current Anthropology, 40 (April 1999), 417-447.

Spreitzer, Elmer, Eldon Snyder E. and Doug Larson, “Age, Education, and Occupation as Correlates of the Meaning of Leisure,” Psychological Reports, 82 (1974), 1105-1106.

Tajfel, Henri and John C. Turner, “An Integrative Theory of Intergroup Conflict,” in W.G. Austin, and S. Worchel eds., The Social Psychology of Intergroup Relation (Monterey, CA: Brooks-Cole, 1979), 33-48.

Tajfel, Henri, John.C. Turner, “The Social Identity Theory of Intergroup Behavior,” In S. Worchel \& W.G. Austin, eds., Psychology of Intergroup Relations (Chicago: Nelson-Hall, 1986), 7-24.

Tarrant, Mark, Adrian C. North and David J. Hargreaves, "Social Categorization, Self-esteem, and the Estimated Musical Preferences of Male Adolescents,” Journal of Social Psychology, 141 (May 2001), 565-581.

Tönnesmann, Wolfgang, “Group Identification and Political Socialization,” In: V. Reynolds, V. Falger, and I. Vine, eds., The Sociobiology of Ethnocentrism: Evolutionary Dimensions of Xenophobia, Discrimination, Racism, and Nationalism (London: Croom Helm, 1987), 175-89.

van den Berghe, Pierre L., “Ethnicity as Kin Selection: The Biology of Nepotism,” In Harris, L. eds., Racism: Key Concepts in Critical Theory, (Amherst, NY, US: Humanity Books, 1999), 5073.

Wade, Peter, "Racial Identity and Nationalism: A Theoretical View from Latin America,” Ethnic and Racial Studies, 24 (May 2001), 845-865.

Wilson, Edward O., On Human Nature (Cambridge, Harvard University Press, 1978). 
Table 1: 'Self' and 'Other' Definitions by Identity Category

\begin{tabular}{|c|c|c|c|}
\hline Identity Category & $\begin{array}{l}\text { Subject's self-characterization in } \\
\text { the background survey }\end{array}$ & $\begin{array}{l}\text { The object is Self relative to the } \\
\text { subject when the 'other person' is } \\
\text { characterized in the experiment } \\
\text { as }\end{array}$ & $\begin{array}{c}\text { The object is Other relative } \\
\text { to the subject when the } \\
\text { 'other person' is } \\
\text { characterized in the } \\
\text { experiment as }\end{array}$ \\
\hline \multirow{8}{*}{ Family and Kinship } & & Your brother & Stranger \\
\hline & & Your close relative & Stranger \\
\hline & & Your father & Stranger \\
\hline & & Your brother-in-law & Stranger \\
\hline & & Your stepfather & Stranger \\
\hline & & Your cousin & Stranger \\
\hline & & Resembles you & Stranger \\
\hline & & Looks like you & Stranger \\
\hline \multirow[t]{2}{*}{ Political Views } & $\begin{array}{c}\text { Politically liberal } \\
\text { (1-3 on a } 6 \text { point scale) }\end{array}$ & Politically liberal & Politically conservative \\
\hline & $\begin{array}{l}\text { Politically conservative } \\
\text { (4-6 on a } 6 \text { point scale) } \\
\end{array}$ & Politically conservative & Politically liberal \\
\hline Sports-team loyalty & & Fan of your favorite sports team & Fan of your rival sports team \\
\hline \multirow{12}{*}{ Music preferences } & Bluegrass is a favorite type & Listens to bluegrass music & \\
\hline & Alternative is a favorite type & Listens to alternative music & \\
\hline & $\begin{array}{c}\text { Contemporary pop/rock is a } \\
\text { favorite type }\end{array}$ & Listens to contemporary pop/rock & \\
\hline & New age is a favorite type & Listens to new age music & \\
\hline & Rap/hip-hop is a favorite type & Listens to rap/hip-hop music & \\
\hline & Opera is a favorite type & Listens to opera music & \\
\hline & $\begin{array}{c}\text { Bluegrass is not listed as a favorite } \\
\text { type }\end{array}$ & & Listens to bluegrass music \\
\hline & $\begin{array}{c}\text { Alternative is not listed as a } \\
\text { favorite type }\end{array}$ & & Listens to alternative music \\
\hline & $\begin{array}{c}\text { Contemporary pop/rock is not a } \\
\text { favorite type }\end{array}$ & & $\begin{array}{l}\text { Listens to contemporary } \\
\text { pop/rock }\end{array}$ \\
\hline & New age is not a favorite type & & Listens to new age music \\
\hline & Rap/hip-hop is not a favorite type & & Listens to rap/hip-hop music \\
\hline & Opera is not a favorite type & & Listens to opera music \\
\hline
\end{tabular}




\begin{tabular}{|c|c|c|c|}
\hline Nationality & American & American & $\begin{array}{c}\text { Chinese, and from France, } \\
\text { Iraq, Argentina, Russia and } \\
\text { Poland } \\
\end{array}$ \\
\hline Religion & $\begin{array}{c}\text { Belongs to a Protestant } \\
\text { denomination }\end{array}$ & Protestant, Lutheran & Muslim, Buddhist, or Jewish \\
\hline \multirow{5}{*}{$\begin{array}{l}\text { Socio-economic } \\
\text { status }\end{array}$} & $\begin{array}{l}\text { Family experienced financial } \\
\text { difficulties while growing up }\end{array}$ & Poor & Financially well-off \\
\hline & Family was financially well-off & Financially well-off & Poor \\
\hline & $\begin{array}{l}\text { Had to work while in high } \\
\text { school }\end{array}$ & Had to work while in high school & $\begin{array}{l}\text { Did not have to work in } \\
\text { high school }\end{array}$ \\
\hline & Father is professional worker & Father is a physician & Father is a factory worker \\
\hline & $\begin{array}{l}\text { Father is unskilled or semiskilled } \\
\text { worker }\end{array}$ & Father is a factory worker & Father is a physician \\
\hline \multirow{2}{*}{ TV viewing } & $\begin{array}{l}\text { Watches TV for at least } 3 \text { hours } \\
\text { a day }\end{array}$ & Watches a lot of TV & Hardly ever watches TV \\
\hline & $\begin{array}{l}\text { Watches TV at most } 1 \text { hour a } \\
\text { day }\end{array}$ & Hardly ever watches TV & Watches a lot of TV \\
\hline \multirow[t]{2}{*}{ Food preferences } & $\begin{array}{l}\text { Convenience foods such as chips } \\
\text { are favorite }\end{array}$ & Eats chips often & Eats salad often \\
\hline & Vegetarian meal is favorite & Vegetarian & Eats hamburger often \\
\hline \multirow{2}{*}{ Birth order } & Youngest child & Youngest child & Oldest child \\
\hline & Oldest child & Oldest child & Youngest child \\
\hline \multirow{4}{*}{ Body Type } & $\begin{array}{l}\text { Taller than } 73 \text { " if male, } 68 \text { " if } \\
\text { female }\end{array}$ & Tall & Short \\
\hline & $\begin{array}{l}\text { Shorter than 58" if female, } 66 " \text { if } \\
\text { male }\end{array}$ & Short & Tall \\
\hline & $\begin{array}{l}\text { Body mass index (definition in } \\
\text { Table 4) } \leq 20 \text { if female, } 20.7 \text { if } \\
\text { male }\end{array}$ & Skinny & Overweight \\
\hline & $\mathrm{BMI} \geq 27$ if female, 27.3 if male & Overweight & Skinny \\
\hline Dress Type & & Dresses like you & $\begin{array}{l}\text { Dresses differently from } \\
\text { you }\end{array}$ \\
\hline \multirow{2}{*}{ Gender } & Female & Female & Male \\
\hline & Male & Male & Female \\
\hline
\end{tabular}


Table 2: Estimated Differences in Behaviors towards 'Self' and 'Other' by Identity Category

Variable

Family
Nationality
Political Views
Television Viewing
Religion

Music Preferences

Food Preferences

Sports Team Loyalty

Socio-economic Status

Body Type

Dress Type

Birth Order

Gender
Regression Giving

(1)

4.264***

$0.992 * *$

$2.524 * * *$

$1.549 * * *$

$2.007 * * *$

$1.995^{* * *}$

$1.415^{* * *}$

$2.586 * * *$

$-0.104$

$0.938 * *$

$1.045^{* *}$

$1.202^{* *}$

$-0.714$
Logit

Share office Work

(2)

(3)

Commute

7.063*** $9.225^{* * *} \quad 9.938^{* * *}$

$4.753^{* * *} \quad 4.048^{* * *} \quad 5.364^{* * *}$

$6.353^{* * *} \quad 5.983^{* * *} \quad 5.289^{* * *}$

$4.610^{* * *} \quad 3.747 * * * \quad 4.929 * * *$

$5.028^{* * *} \quad 4.321^{* * *} \quad 4.433^{* * *}$

$7.475^{* * *} \quad 6.798^{* * *} \quad 5.163^{* * *}$

3.375*** $3.144^{* * *} \quad 3.117^{* * *}$

$6.006^{* * *} \quad 4.981^{* * *} \quad 4.410^{* * *}$

$4.429 * * * \quad 2.924 * * * \quad 4.829 * * *$

$2.184 * *$

$1.865 * *$

$2.186^{* *}$

1.783

$2.692 * * * \quad 1.514$

$2.957 * *$

$2.004 *$

$2.468 * * *$

$-2.232 * *$

$-1.420 *$

Note: The table reports estimated differences in behaviors towards Self and Other based on the fixed-effect estimates reported in Appendix Table A1. Significance tests are based on two-sided asymptotic z-tests of differences in the SelfOther estimated coefficients for each identity category. One, two and three asterisks indicate statistical significance at the $10 \%, 5 \%$ and $1 \%$ levels, respectively. 
Table 3: Ranks of Self-Other Differences for Giving Summary Statistics from Bootstrap replications

\begin{tabular}{|c|c|c|c|}
\hline Variable & Mean Rank & 5th Percentile & 95th Percentile \\
\hline Family & 1 & 1 & 1 \\
\hline Nationality & 9.721 & 8 & 11 \\
\hline Political Views & 2.761 & 2 & 5 \\
\hline Television Viewing & 6.58 & 4 & 9 \\
\hline Religion & 4.469 & 3 & 6 \\
\hline Music Preferences & 4.509 & 3 & 6 \\
\hline Food Preferences & 7.036 & 6 & 9 \\
\hline Sports Team Loyalty & 2.521 & 2 & 3 \\
\hline Socio-economic Status & 12.371 & 12 & 13 \\
\hline Body Type & 10.015 & 8 & 11 \\
\hline Dress Type & 9.269 & 7 & 11 \\
\hline Birth Order & 8.361 & 6 & 11 \\
\hline Gender & 12.387 & 10 & 13 \\
\hline
\end{tabular}


Table 4: Test of equality of coefficients across behaviors by identity category

\begin{tabular}{|l|c|c|c|}
\hline & Share-Work & Share-Commute & Commute-Work \\
\hline \hline Family & $11.61^{* * *}(-)$ & $9.01(-)^{* * *}$ & $0.03(+)$ \\
\hline Nationality & $0.16(-)$ & $0.01(-)$ & $0.08(-)$ \\
\hline Political Views & $2.17(+)$ & $0.17(-)$ & $3.02(+)^{*}$ \\
\hline Television Viewing & $0.01(-)$ & $0.01(+)$ & $0.03(-)$ \\
\hline Religion & $1.34(+)$ & $0.01(-)$ & $1.15(+)$ \\
\hline Music Preferences & $11.28(+)^{* * *}$ & $0.02(-)$ & $8.93(+)^{* * *}$ \\
\hline Food Preferences & $0.45(+)$ & $0.25(-)$ & $1.26(+)$ \\
\hline Sports Team Loyalty & $4.94(+)^{* *}$ & $0.05(+)$ & $2.80(+)^{*}$ \\
\hline $\begin{array}{l}\text { Socio-economic } \\
\text { Status }\end{array}$ & $0.04(-)$ & $0.67(+)$ & $1.15(-)$ \\
\hline Body Type & $0.11(+)$ & $0.24(-)$ & $0.63(+)$ \\
\hline Dress Type & $0.35(-)$ & $2.33(-)$ & $4.58(+)^{* *}$ \\
\hline Birth Order & $0.56(+)$ & $0.01(+)$ & $0.28(+)$ \\
\hline
\end{tabular}

Note:

Each cell shows the chi-square test statistic. (-) indicates that the estimate on the first-listed behavior presented in Table 2 is smaller than the estimate on the second-listed behavior; (+) indicates the opposite. One, two and three asterisks indicate statistical significance at the $10 \%, 5 \%$ and $1 \%$ levels, respectively. 


\section{Appendix}

Table A1: Fixed-Effects Regression and Fixed-Effects Logit Estimates

\begin{tabular}{|c|c|c|c|c|}
\hline \multirow[t]{2}{*}{ Variable } & \multicolumn{2}{|l|}{ Regression } & \multicolumn{2}{|l|}{ Logit } \\
\hline & $\begin{array}{l}\text { Giving } \\
\text { (1) }\end{array}$ & $\begin{array}{c}\text { Share Office } \\
\text { (2) }\end{array}$ & $\begin{array}{l}\text { Work } \\
\text { (3) }\end{array}$ & $\begin{array}{c}\text { Commute } \\
\text { (4) }\end{array}$ \\
\hline \multirow{2}{*}{ Family } & $-1.175^{* * *}$ & -5.084 & -5.985 & -5.074 \\
\hline & $(0.213)$ & $(0.48)$ & $(0.423)$ & $(0.422)$ \\
\hline \multirow{2}{*}{ Nationality } & -0.485 & -2.702 & -2.716 & -1.8 \\
\hline & $(0.163)$ & $(0.456)$ & $(0.379)$ & $(0.39)$ \\
\hline \multirow{2}{*}{ Political Views } & -1.071 & -4.655 & -3.418 & -3.884 \\
\hline & $(0.224)$ & $(0.486)$ & $(0.424)$ & $(0.427)$ \\
\hline \multirow{2}{*}{ Television Viewing } & -0.629 & -3.087 & -3.107 & -2.401 \\
\hline & $(0.192)$ & $(0.474)$ & $(0.399)$ & $(0.412)$ \\
\hline \multirow{2}{*}{ Religion } & -0.809 & -3.562 & -3.05 & -2.737 \\
\hline & $(0.168)$ & $(0.458)$ & $(0.382)$ & $(0.392)$ \\
\hline \multirow{2}{*}{ Music Preferences } & -0.936 & -4.372 & -3.249 & -3.402 \\
\hline & $(0.166)$ & $(0.457)$ & $(0.381)$ & $(0.39)$ \\
\hline \multirow{2}{*}{ Food Preferences } & -0.683 & -2.625 & -2.291 & -1.857 \\
\hline & $(0.179)$ & $(0.468)$ & $(0.394)$ & $(0.405)$ \\
\hline \multirow{2}{*}{ Sports Team Loyalty } & -1.284 & -3.505 & -3.08 & -2.669 \\
\hline & $(0.213)$ & $(0.485)$ & $(0.417)$ & $(0.426)$ \\
\hline \multirow{2}{*}{ Socio-economic Status } & 0.353 & -2.838 & -2.761 & -1.791 \\
\hline & $(0.172)$ & $(0.462)$ & $(0.385)$ & $(0.398)$ \\
\hline \multirow{2}{*}{ Body Type } & -0.643 & -2.282 & -1.9 & -1.441 \\
\hline & $(0.173)$ & $(0.465)$ & $(0.391)$ & $(0.404)$ \\
\hline \multirow{2}{*}{ Dress Type } & -0.485 & -1.732 & -1.306 & -1.604 \\
\hline & $(0.213)$ & $(0.517)$ & $(0.451)$ & $(0.447)$ \\
\hline \multirow{2}{*}{ Birth Order } & -0.35 & -2.471 & -2.155 & -0.799 \\
\hline & $(0.205)$ & $(0.529)$ & $(0.419)$ & $(0.458)$ \\
\hline \multirow{2}{*}{ Self $x$ Family } & 2.374 & -0.284 & 1.462 & 2.697 \\
\hline & $(0.537)$ & $(0.895)$ & $(0.958)$ & $(0.597)$ \\
\hline \multirow{2}{*}{ Self $x$ Nationality } & -0.208 & -0.187 & 0.133 & 0.826 \\
\hline & $(0.538)$ & $(0.947)$ & $(0.995)$ & $(0.692)$ \\
\hline \multirow{2}{*}{ Self x Political Views } & 0.738 & -0.537 & 0.133 & 0.826 \\
\hline & $(0.563)$ & $(0.919)$ & $(0.986)$ & $(0.636)$ \\
\hline \multirow{2}{*}{ Self $x$ Television Viewing } & 0.206 & -0.72 & -0.653 & -0.079 \\
\hline & $(0.583)$ & $(0.985)$ & $(1.019)$ & $(0.701)$ \\
\hline \multirow{2}{*}{ Self $x$ Religion } & 0.484 & -0.77 & -1.131 & 0.162 \\
\hline & $(0.531)$ & $(0.897)$ & $(0.952)$ & $(0.6)$ \\
\hline \multirow{2}{*}{ Self $x$ Music Preferences } & 0.344 & 0.876 & -0.604 & 2.005 \\
\hline & $(0.535)$ & $(0.916)$ & $(0.96)$ & $(0.643)$ \\
\hline \multirow[t]{2}{*}{ Self x Food Preferences } & 0.018 & -1.417 & -1.615 & -0.138 \\
\hline & $(0.536)$ & $(0.908)$ & $(0.961)$ & $(0.62)$ \\
\hline
\end{tabular}


Table A1 (continued):

\begin{tabular}{|c|c|c|c|c|}
\hline \multirow[t]{2}{*}{ Variable } & \multirow{2}{*}{$\begin{array}{c}\text { Regression } \\
\text { Giving } \\
\text { (1) } \\
\end{array}$} & \multicolumn{3}{|c|}{ Logit } \\
\hline & & $\begin{array}{c}\text { Sharing } \\
\text { (2) }\end{array}$ & $\begin{array}{c}\text { Working } \\
\text { (3) } \\
\end{array}$ & $\begin{array}{c}\text { Commute } \\
(4) \\
\end{array}$ \\
\hline \multirow{2}{*}{ Self $x$ Sports Team Loyalty } & 0.587 & 0.259 & -1.187 & 0.888 \\
\hline & $(0.555)$ & $(0.944)$ & $(0.974)$ & $(0.659)$ \\
\hline \multirow{2}{*}{ Self $x$ Socio-economic Status } & -0.465 & -0.646 & -0.446 & -0.289 \\
\hline & $(0.49)$ & $(0.834)$ & $(0.897)$ & $(0.498)$ \\
\hline \multirow{2}{*}{ Self x Body Type } & -0.419 & -2.335 & -2.224 & -0.996 \\
\hline & $(0.547)$ & $(0.919)$ & $(0.974)$ & $(0.637)$ \\
\hline \multirow{2}{*}{ Self x Dress Type } & -0.154 & -2.183 & -2.301 & -0.333 \\
\hline & $(0.555)$ & $(0.948)$ & $(1)$ & $(0.668)$ \\
\hline \multirow{2}{*}{ Self $x$ Birth Order } & 0.138 & -1.756 & -2.197 & -0.216 \\
\hline & $(0.563)$ & $(1.019)$ & $(0.991)$ & $(0.801)$ \\
\hline \multirow{2}{*}{ Self $x$ Gender } & -0.714 & -2.231 & -2.505 & -1.418 \\
\hline & $(0.555)$ & $(1.076)$ & $(1.058)$ & $(0.749)$ \\
\hline \multirow{2}{*}{ Constant } & 2.978 & - & - & - \\
\hline & $(0.255)$ & & & \\
\hline Number of Observations & 10660 & 8784 & 8695 & 8484 \\
\hline \multirow[t]{2}{*}{ Person-Self-Other Groups } & 402 & 345 & 335 & 312 \\
\hline & $\mathbf{R}^{2}=0.0752$ & $\begin{array}{c}\text { Log Likelihood= } \\
-2964.92\end{array}$ & $\begin{array}{c}\text { Log Likelihood }= \\
-2946.01\end{array}$ & $\begin{array}{c}\text { Log Likelihood }= \\
-2675.67\end{array}$ \\
\hline
\end{tabular}

Note: Each observation corresponds to a particular person-identity category-Self/Other value. For the fixed-effects logit estimates, all observations in which Self/Other-identity category groups have no variation in the dependent variable are dropped from the estimations. One, two and three asterisks indicate statistical significance at the $10 \%, 5 \%$ and $1 \%$ levels, respectively; standard errors are in parentheses. 
Figure 1: 'Self' and 'Other' Comparisons by Identity Category
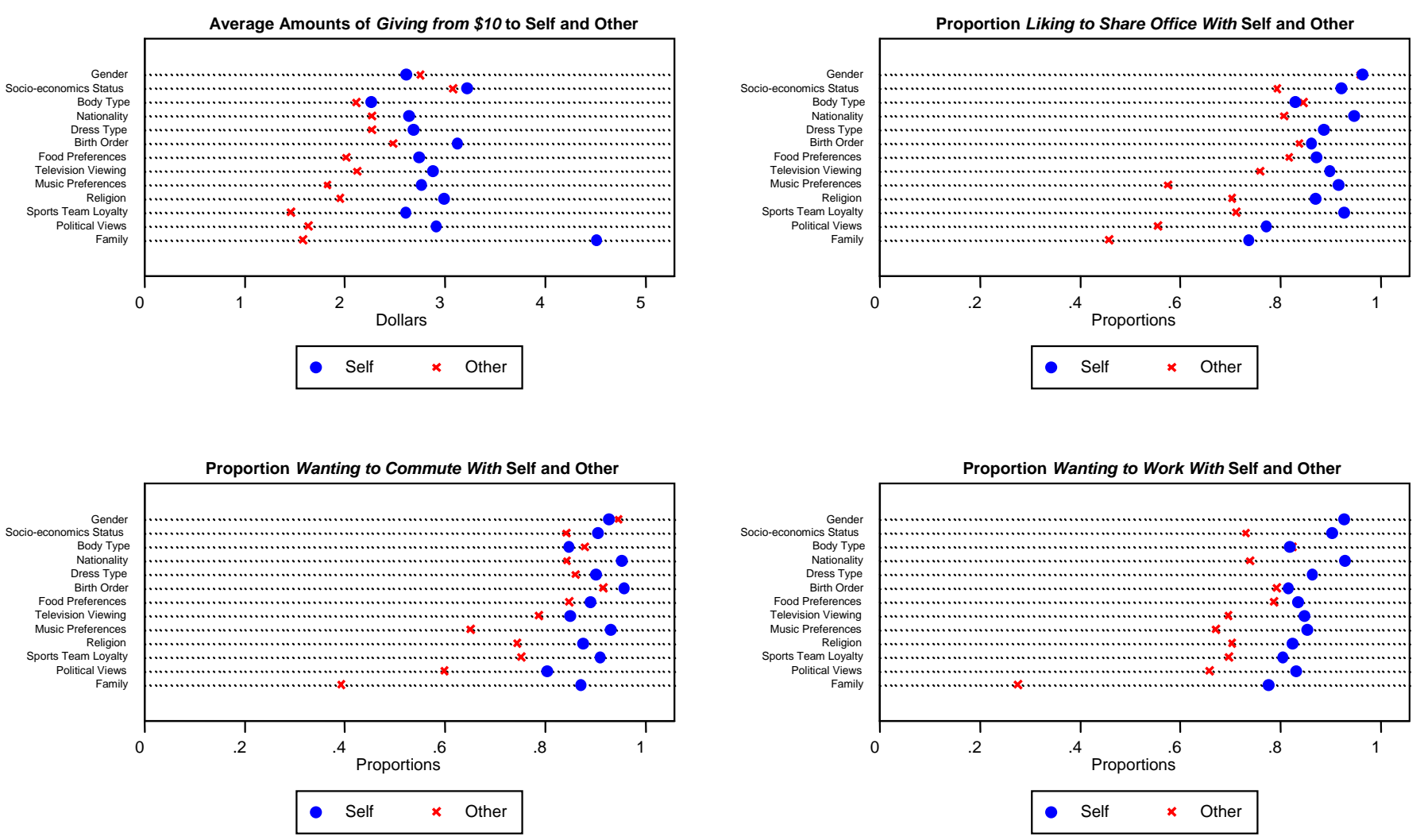

Source: see text for details 